\title{
Shareholder Engagement for Corporate Governance in the Light of the Harmonization and Transposition
}

\author{
Submitted 28/07/19, $1^{\text {st }}$ revision 15/08/19, $2^{\text {nd }}$ revision 20/09/19, accepted 21/10/19
}

\author{
Robert K. MacGregor ${ }^{1}$, Radka MacGregor Pelikánová ${ }^{2}$
}

\begin{abstract}
:
Purpose: This comparative study holistically assesses the EU harmonization and various transposition strategies embraced by EU member states to implement measures for corporate governance, namely for the sustainable corporate governance.

Design/Methodology/Approach: The contribution and the relevant methodology is based on a duality of purposes. They are (i) on a review and analysis of EU harmonization endeavors designed to shape the exercise of shareholders rights and specifically encouraging a longterm shareholder engagement as the vehicle to increase corporate social responsibility (CSR) and (ii) on a pioneering critical comparative Meta-analysis of selected transposition strategies and their potential to testify about the genuiness of the underlying commitment.

Findings: Based on the holistically implied arguments and yielded results, it is proposed that, despite rather clear EU harmonization measures, there are dramatic differences in transposition strategies testifying about deep differences in the approach to corporate governance and CSR across the EU.

Practical implications: Based on addressing its dual purposes, this study sheds a new light on the perception and attitude to the corporate governance, shareholder long-term engagement, CSR and their framework in the EU. This leads to a set of recommendations to increase the effectiveness and efficiency of the current harmonization endeavors.

Originality/Value: Although this study organically builds upon recent studies about corporate governance and CSR, it brings a pioneering comparative assessment of transposition strategies and an innovative idea to use it as a well founded instrument to understand and appreciate the harmonization potential in this field and to improve it.
\end{abstract}

Keywords: Corporate governance, Corporate Social Responsibility (CSR), Harmonization measures, Shareholder engagement, Sustainability, Transposition.

JEL Codes: G39, K22, L22, M10, 038.

Paper Type: Research Paper.

\footnotetext{
${ }^{1}$ Eastern Michigan University, USA, Master Program Graduate and Free-lance researcher and writer, robertkmacgregor@yahoo.com

${ }^{2}$ Academic Lecturer and Researcher, Metropolitan University Prague, Department of International Business, radkamacgregor@yahoo.com
} 
Acknowledgments:

This research and resulting contribution are the result of Metropolitan University Prague research project no. 68-02 "Territorial Studies, Economics, International Relations" (2019) based on a grant from the Institutional Fund for the Long-term Strategic Development of Research Organisations.

\section{Introduction}

Two decades ago, the global society, including the EU and EU member states, faced a set of economic, financial, real estate, employment and other crises (Egedi, 2012, Jędrzejowska-Schiffauer et al., 2019; Tvrdoň et al., 2012;; Tvrdoň, 2016; Thalassinos \& Thalassinos, 2018). This prompted the EU to introduce a myriad of measures, general and specific, mandatory and facultative (Jędrzejowska-Schiffauer et al., 2019). As the general umbrella for the majority of these endeavors, the EU launched the ten year long strategy, Europe 2020, for smart, sustainable and inclusive growth in the context of the single internal market ("Strategy Europe 2020") (EC, 2010). Undoubtedly the pivotal policy instrument for 2010-2020 for competition, sustainability and even e.g. corporate governance issues in the EU is this very Strategy Europe 2020 (Staníčková, 2017; MacGregor-Pelikánová, 2019a). This policy is translated into a myriad of instruments.

With respect to shareholder companies and their sustainable corporate governance and due to the competence spheres of the EU law, these instruments include predominantly general and special Directives. These general Directives include Directive 2013/34/EU on annual financial statements, consolidated financial statements and related reports of certain types of undertakings as novelized in 2014 ("Directive 2013/34"). These special Directives include Directive 2007/36/EC on the exercise of certain rights of shareholders in listed companies ("Directive 2007/36") and Directive 2017/828 amending Directive 2007/36 as regards the encouragement of long-term shareholder engagement ("Directive 2017/282").

It is relevant and legitimate to explore this newly updated harmonization regime and its application, in particular while considering the employment of harmonization and transposition strategies. Therefore the primary purpose of this study is a review and analysis of EU harmonization endeavors designed to shape the exercise of shareholders rights to improve corporate governance and specifically encouraging a long-term shareholder engagement as the vehicle to increase competitiveness and responsibility, including corporate social responsibility ("CSR"), namely Directive 2007/36 and Directive 2017/282.

The secondary purpose is to comparatively describe and critically assess the transposition strategies, i.e. to perform a pioneering critical comparative Metaanalysis of selected transposition strategies and their potential to testify about the genuiness of the underlying commitment. The originality and relevance of these endeavors is further magnified by the fact that the transposition deadline for 
Directive 2017/828 expired recently, on 10 June 2019, and that there are already a few interesting cases of the Court of Justice of EU ("CJ EU") regarding Directive 2007/36. Both purposes are interrelated and require the exploration of legislative, academic and other sources while focusing on both qualitative and quantitative aspects. The need to overcome this fragmentation and diversification leads to the selection of the holistic approach and Meta-Analysis. Consequenty, the Literature review and legislative background provides the foundation, data and research methods indicated by the methodology, while a deeper study of Directive 2007/36, especially its amendments by Directive 2017/282, offers an insight about the harmonization framework.

Thereafter, a pioneering comparative study of transposition strategies is presented and leads to a discussion over results, which culminates in conclusions sheding a new light in the understanding and appreciation of shareholder engagement as a determinant of a sustainable corporate governance and offering recommendations for further improvements and an increase in the effectiveness, efficiency and sustainability.

\section{Literature Review and Legislative Background}

The global society of the $21^{\text {st }}$ century is shaped by vigorous, if not aggressive competition (MacGregor-Pelikánová, 2017), advanced complex integration (Piekarczyk, 2016), human development (Polcyn, 2018), progressive digitalization (Vivant, 2016), and enhanced innovations (Pohulak-Żołędowska, 2016). The post WW II European integration project mixes supranational and intergovernmental approaches and inevitably is founded upon both common law and continental law traditions (MacGregor-Pelikánová, 2012) and is shaped by political desire, historical truth and economic reality (Chirita, 2014) and institutional features influenced by competing interest groups (Damro, 2012). The resulting EU law has many faces and in certain spheres is omnipotent, while in others powerless. The EU primary law has intergovernmental features, serves as the constitutional foundation of the EU and includes three documents implying that there are conferred exclusive, conferred shared and not conferred competencies and that the EU recognized fundamental rights and liberties (MacGregor-Pelikánová, 2017).

These three documents are the Treaty on EU ("TEU"), Treaty on the functioning of EU ("TFEU") and Charter of fundamental rights of the EU ("Charter"). Both the EU secondary law, such as Regulation and Directive, and EU supplementary law, such as the case law of the CJ EU, have rather a supranational nature and have to be in compliance with the EU primary law (MacGregor-Pelikánová, 2017). The EU law is projected in the EU strategies, such as the Strategy Europe 2020, which are typically prepared by the European Commission and are influenced by both formal and informal institutions (Pasimeni and Pasimeni, 2016). They are shaped as a policy for the economic dominance of the EU on the global market (Stec and Grzebyk, 2017) and as a vehicle for sustainability and Corporate Social Responsibility ("CSR"). The 
modern concept of sustainability emerged in the 1960's in the USA, was incorporated in the United Nations Brundtland Report 1987 and led to CSR as a merger of the systematic and visionary soft law self-regulation of businesses with normatively and morally regulated corporate responsibility (Bansal and Song, 2017; Hahn et al., 2018).

The Strategy Europe 2020 is intimately linked to the concept of the single internal market with a certain they match up their vision, mission and resources, it provides for the determination and matching of objectives and the means for attaining them (Jędrzejowska-Schiffauer et al., 2019). The corporate governance is pivotal for the interaction of all stakeholders of the enterprise, especially its top management and shareholders, their engagement as well as for its sustainable competitiveness. Indeed, an effective, efficient and sustainable corporate governance requires an effective, efficient and sustainable shareholder engagement entailing right on profits (dividends), to vote and get information (Jędrzejowska-Schiffauer et al., 2019; MacGregor-Pelikánová, 2019c).

In the case of financial institutions as well as other enterprises, it can be observed that the principal-agent dilemma, competitivenss and the sustainability and CSR issues linked to the corporate governance can be better addressed if the shareholder engagement is deeper and long-standing. This is significant for the success of the modern EU integration and the meeting of the Strategy Europe 2020. Therefore, the EU uses in particular its conferred shared competence to build both hard and soft frameworks, including Directive 2013/34 and Directive 2007/36 updated by Directive 2017/828. However, what is the reality, in particular with respect to harmonized shareholder engagement as a determinant of sustainable corporate governance?

\section{Data and Research Methods}

The contribution and the relevant methodology is based on a duality of purposes, the first of which is a review and analysis of EU harmonization endeavors designed to shape the exercise of shareholder's rights and specifically encouraging a longterm shareholder engagement as the vehicle to increase corporate social responsibility (CSR) as well as to improve corporate governance. Secondly, on a pioneering critical comparative Meta-Analysis of selected transposition strategies and their potential to testify about the genuiness of the underlying commitment. These two purposes are interrelated and are a clarion call for the study of EU harmonization measures, Directive 2007/36 and its amendment by Directive 2017/828, and EU member state's national measures transposing these EU measures, along with a cursory overview of the relevant case law generated by the CJ EU.

The combined understanding of the EU harmonization framework, of the transposition strategies and of the CJ EU case law should facilitate the confirmation 
or rejection of the expectation (hypothesis) that a message can be drawn. And if the hypothesis is confirmed, then naturally it should be holistically and plainly stated what exactly this message says and what it means.

Or, to put it another way, how can we take advantage of the established knowledge and thus improve the sustainable corporate governance? In order to properly address both purposes, the suggested hypothesis about the existence of a message and related research sub-questions and hypothesis, the already accomplished legislative and literature review needs to be expanded by using a holistic, open minided MetaAnalysis able to address the the heterogeneous nature of the sources (Silverman, 2013) and enhanced by Socratic questioning (Areeda, 1996). The legislative, judiciary, economic and technical aspects shape the focus, targeting both qualitative and quantitative data and entailing deductive and inductive aspects of legal thinking (MacGregor-Pelikánová, 2019c) and certainly building upon the text analysis, especially content and qualititative text analysis (Kuckartz, 2014).

A legislative research and comparative critical analysis needs to be done regarding the EU harmonization measures obtained from the Eur-Lex Database, national transposition strategies obtained from Eur-Lex Database and national law databases, and the cases of the CJ EU transposition in EU member states. Further, a research of the CJ EU case law via the Curia database needs to be done while focusing both on direct and indirect actions and the extracted cases have to be mined and explored while using a teleological and purposive approach. The yielded results and related discussion proposes answers, or at least indications for answers, to the research subquestions, confirms the hypothesis and offers an interesting message about the current national status quo attitude to the shareholder engagement as a determinant of sustainable corporate governance.

\section{EU harmonization of the exercise of shareholder rights and of the long term engagement - Directive 2007/36 and Directive 2017/828}

On the eve of the wave of crises, the EU Parliament and the Council of the EU adopted a rather short and specific Directive 2007/36. Although the Directive $2007 / 36$ is an outcome of a project launched in 2003 under an ambitous title "Modernising Company Law and enhancing Corporate Governance in the EU - A Plan to Move Forward," its reach is rather narrow - the exercise of certain shareholder rights attached to voting shares of EU companies which are admitted to trading on a regulated market in the EU (Art.1). Hence, it deals only with shareholder rights regarding general meetings of listed companies, specifically the information right (Art.5 and Art.9), agenda and participation right (Art.6-8), manner of exerice of voting right (Art.10-14) in a listed company, see Table 1. The fundamental principle is the principle of equal treatment (Art.4) and the general transposition deadline was set for 3 August 2008 and the special transposition deadline for proxy was set for 3 August 2012 (Art.15). 
Table 1. Selected provisions of Directive 2007/36

\begin{tabular}{|l|l|l|}
\hline Art.1 & $\begin{array}{l}\text { Subject-matter } \\
\text { and scope }\end{array}$ & $\begin{array}{l}\text { 1. This Directive establishes requirements in relation to the } \\
\text { exercise of certain shareholder rights attached to voting shares } \\
\text { in relation to general meetings of companies which have their } \\
\text { registered office in a Member State and whose shares are } \\
\text { admitted to trading on a regulated market situated or operating } \\
\text { within a Member State. }\end{array}$ \\
\hline Art.3 & $\begin{array}{l}\text { Further national } \\
\text { measures }\end{array}$ & $\begin{array}{l}\text { This Directive shall not prevent Member States from imposing } \\
\text { further obligations on companies or from otherwise taking } \\
\text { further measures to facilitate the exercise by shareholders of the } \\
\text { rights referred to in this Directive. }\end{array}$ \\
\hline Art.9 & $\begin{array}{l}\text { Right to ask } \\
\text { questions }\end{array}$ & $\begin{array}{l}\text { 1. Every shareholder shall have the right to ask questions } \\
\text { related to items on the agenda of the general meeting. The } \\
\text { company shall answer the questions put to it by shareholders... }\end{array}$ \\
\hline Voting results & $\begin{array}{l}\text { 1. The company shall establish for each resolution at least the } \\
\text { number of shares for which votes have been validly cast, the } \\
\text { proportion of the share capital represented by those votes, the } \\
\text { total number of votes validly cast as well as the number of } \\
\text { votes cast in favour of and against each resolution and, where } \\
\text { applicable, the number of abstentions. However, Member } \\
\text { States may provide or allow companies to provide that, if no } \\
\text { shareholder requests a full account of the voting, it shall be } \\
\text { sufficient to establish the voting results only to the extent } \\
\text { needed to ensure that the required majority is reached for each } \\
\text { resolution. }\end{array}$ \\
\hline
\end{tabular}

Source: Processing performed by the authors based on Eur-Lex.

Exactly around the time of adoption (2007) and transposition deadline (2008), the mentioned set of crises had already brought its noticeable negative impact on the EU and so Directive 2007/36 with its drive for more information and more involvement of shareholders in listed companies seemed as a welcome and much needed prophetic instrument addressing new challenges. This points to the expectations that this narrow and logically harmonization instrument was smoothly, duly and timely transposed by all EU member states. Nevertheless, the below analysis regarding transposition strategies and cases offers a different picture.

Directive 2007/36 was amended twice. The first amendment was done via Directive 2014/59 establishing a framework for the recovery and resolution of credit institutions and investment firms and brought changes regarding Art.1 and Art.5 of the Directive 2007/36. These changes are marginal for this contribution, i.e. for the shareholder engagement as a determinant of sustainable corporate governance. In contrast, the second amendment of Directive 2007/36, i.e. the amendment by Directive 2017/828 is truly significant in this respect. Directive 2017/828 not only changed Art. 1 and Art. 2 of Directive 2007/36, but even dramatically expanded Art.3, Art.9 and Art.14. Table 2 reveals specific provisions dealing with corporate governance and encouragement of (long standing) shareholder engagement. 
Table 2. Selected provisions of Directive 2007/36 brought by Directive 2017/828

\begin{tabular}{|c|c|c|}
\hline Art.1 & $\begin{array}{l}\text { Subject-matter } \\
\text { and scope }\end{array}$ & $\begin{array}{l}\text { 1. This Directive establishes requirements in relation to the } \\
\text { exercise of certain shareholder rights attached to voting } \\
\text { shares in relation to general meetings of companies which } \\
\text { have their registered office in a Member State and the shares } \\
\text { of which are admitted to trading on a regulated market } \\
\text { situated or operating within a Member State. It also } \\
\text { establishes specific requirements in order to encourage } \\
\text { shareholder engagement, in particular in the long term. Those } \\
\text { specific requirements apply in relation to identification of } \\
\text { shareholders, transmission of information, facilitation of } \\
\text { exercise of shareholders rights, transparency of institutional } \\
\text { investors, asset managers and proxy advisors, remuneration } \\
\text { of directors and related party transactions. }\end{array}$ \\
\hline Art.3a & $\begin{array}{l}\text { Identification of } \\
\text { shareholders }\end{array}$ & $\begin{array}{l}\text { 1. Member States shall ensure that companies have the right } \\
\text { to identify their shareholders. Member States may provide } \\
\text { for companies having a registered office in their territory to } \\
\text { be only allowed to request the identification of shareholders } \\
\text { holding more than a certain percentage of shares or voting } \\
\text { rights. Such a percentage shall not exceed } 0,5 \% \text {. }\end{array}$ \\
\hline Art.3b & $\begin{array}{l}\text { Transmission of } \\
\text { information }\end{array}$ & $\begin{array}{l}\text { 1. Member States shall ensure that the intermediaries are } \\
\text { required to transmit the following information, without } \\
\text { delay, from the company to the shareholder or to a third party } \\
\text { nominated by the shareholder:.. }\end{array}$ \\
\hline Art.3c & $\begin{array}{l}\text { Facilitation of } \\
\text { the exercise of } \\
\text { shareholder } \\
\text { rights }\end{array}$ & $\begin{array}{l}\text { 1. Member States shall ensure that the intermediaries } \\
\text { facilitate the exercise of the rights by the shareholder, } \\
\text { including the right to participate and vote in general } \\
\text { meetings, which shall comprise at least one of the } \\
\text { following:.. }\end{array}$ \\
\hline Art.3d & $\begin{array}{l}\text { Non- } \\
\text { discrimination, } \\
\text { proportionality } \\
\text { and } \\
\text { transparency of } \\
\text { costs }\end{array}$ & $\begin{array}{l}\text { 1. Member States shall require intermediaries to disclose } \\
\text { publicly any applicable charges for services provided for } \\
\text { under this Chapter separately for each service... }\end{array}$ \\
\hline Art.3i & $\begin{array}{l}\text { Transparency of } \\
\text { asset managers }\end{array}$ & $\begin{array}{l}\text { 1. Member States shall ensure that asset managers disclose, } \\
\text { on an annual basis, to the institutional investor with which } \\
\text { they have entered into the arrangements referred to in Article } \\
\text { 3h how their investment strategy and implementation thereof } \\
\text { complies with that arrangement and contributes to the } \\
\text { medium to long-term performance of the assets of the } \\
\text { institutional investor or of the fund.... }\end{array}$ \\
\hline Art.9a & $\begin{array}{l}\text { Right to vote on } \\
\text { the } \\
\text { remuneration } \\
\text { policy }\end{array}$ & $\begin{array}{l}\text { 1. Member States shall ensure that companies establish a } \\
\text { remuneration policy as regards directors and that } \\
\text { shareholders have the right to vote on the remuneration } \\
\text { policy at the general meeting... }\end{array}$ \\
\hline Art.9b & $\begin{array}{l}\text { Information to } \\
\text { be provided in } \\
\text { and right to vote }\end{array}$ & $\begin{array}{l}\text { 1. Member States shall ensure that the company draws up a } \\
\text { clear and understandable remuneration report, providing a } \\
\text { comprehensive overview of the remuneration, including all }\end{array}$ \\
\hline
\end{tabular}




\begin{tabular}{|l|l|l|}
\hline & $\begin{array}{l}\text { on the } \\
\text { remuneration } \\
\text { report }\end{array}$ & $\begin{array}{l}\text { benefits in whatever form, awarded or due during the most } \\
\text { recent financial year to individual directors, including to } \\
\text { newly recruited and to former directors, in accordance with } \\
\text { the remuneration policy referred to in Article 9a... }\end{array}$ \\
\hline Art.9c & $\begin{array}{l}\text { Transparency } \\
\text { and approval of } \\
\text { related party } \\
\text { transactions }\end{array}$ & $\begin{array}{l}\text { 1. Member States shall define material transactions for the } \\
\text { purposes of this Article, .. When defining material } \\
\text { transactions Member States shall set one or more quantitative } \\
\text { ratios based on the impact of the transaction on the financial } \\
\text { position, revenues, assets, capitalization, including equity, or } \\
\text { turnover of the company or take into account the nature of } \\
\text { transactions and the position of the related party. }\end{array}$ \\
\hline Art.14b & $\begin{array}{l}\text { Measures and } \\
\text { penalties }\end{array}$ & $\begin{array}{l}\text { Member States shall lay down the rules on measures and } \\
\text { penalties applicable to infringements of national provisions } \\
\text { adopted pursuant to this Directive and shall take all measures } \\
\text { necessary to ensure that they are implemented. }\end{array}$ \\
\hline
\end{tabular}

Source: Processing performed by the authors based on Eur-Lex.

The transposition deadline for Directive 2017/828, i.e. for the transpositions of amendments to Directive 2007/36 was set for 10 June 2019. Therefore, even for this it might be suggested that the recent transposition should have been smoothly, duly and timely completed.

\section{National Transposition Strategies regarding Directive 2007/36 and Directive 2017/828}

The general transposition period for the Directive 2007/36 expired on 3 August 2008 and many EU member states had not manged to meet it. Ultimately, the transposition has been completed in all EU member states and Table 3, below, summarizes the number of transposition instruments and their timeline for selected EU member states.

Table 3. National transposition of the original Directive 2007/36 for general matters (deadline 3 August 2009): selected states with number of measures + the year of the last one

\begin{tabular}{|l|l|l|l|l|l|l|l|l|l|l|l|}
\hline State & BE & CZ & GE & EE & ES & FR & IT & LU & AT & PL & UK \\
\hline Nr. & 2 & 8 & 2 & 1 & 1 & 5 & 1 & 1 & 1 & 1 & 2 \\
\hline Date & 2011 & 2012 & 2009 & 2009 & 2011 & 2010 & 2010 & 2011 & 2009 & 2009 & 2011 \\
\hline
\end{tabular}

Source: Processing performed by the authors based on Eur-Lex.

Table 3 reveals that, despite the relative simplicity, narrowness and relevancy of the original Directive 2007/36, many EU member states failed to complete the transposition by the deadline. This rather surprising statement is confirmed by the analyses of the case law of the CJ EU via the Database Curia.eu. Indeed, in at least five cases the European Commission brought a direct action to the CJ EU demanding they declare that a EU member state failed to adjust its national law to be compatible with the Directive 2007/36 and to communicate about it. These cases are C-428/10 
Commission v. France, C-410/10 Commission v. Greece, C-391/10 Commission v. Belgium, C-390/10 Commission v. Luxembourg and C-375/10 Commission v. Spain and in all of them the defending EU member state has not brought any objections or arguments against the charges and so the CJ EU ruled that any such EU member state had failed to fulfill its obligations and ordered such a 'guilty' EU member state to pay the related costs. Further, Table 3 reveals that, following this, all condemned EU member states promptly transposed the Directive 2007/36.

Directive 2017/828 has brought many changes to the current systems and developed new special mechanisms targeting the corporate governance and long term shareholder engagement, as is obvious from Table 2 above. Therefore, and considering the described not truly smooth and timely transposition of the Directive 2007/36, it might be suspected that a resistance, or at least procrastination or delay will occur. The general deadline expired on 10 June 2019 and Table 4, below, reveals the fragmented natures of the transposition across the EU.

Table 4. National transposition of the Directive 2017/828 (deadline 10 June 2019): selected states with the number of measures + the year of the last one

\begin{tabular}{|l|l|l|l|l|l|l|l|l|l|l|l|}
\hline State & BE & CZ & GE & EE & ES & FR & IT & LU & AT & PL & UK \\
\hline Nr. & 0 & 3 & 1 & 1 & 0 & 1 & 1 & 1 & 3 & 0 & 6 \\
\hline Date & $!$ & 2019 & 2019 & 2018 & $!$ & 2019 & 2019 & 2019 & 2019 & $!$ & 2019 \\
\hline
\end{tabular}

Source: Processing performed by the authors based on Eur-Lex.

Thusly, certain EU member states have not even partially transposed the new harmonization regime $(\mathrm{BE}, \mathrm{ES})$ and one might speculate that the EU law perspective and drive for the long term shareholder engagement and the related corporate governace changes are not fully welcome in these jurisdictions. In other jurisdictions, the low number of transposition measures and their nature might raise suspicions about the completeness of the transposition. Even more interestingly, regarding the EU push for the engagement of long-term shareholder engagement, the UK ranks first and foremost as the most complying and truly going in depth EU member state. The performed search and study brings forth only a few conclusive answers and rather leads to many other questions and recommendations.

\section{Conclusions and Recommendations}

Following the stated dual purposes, the provided comparative review with holistic Meta-Analysis confirms the hypothesis that a message, indeed two messages, can be implied, and accordingly offers recommendations.

Firstly, along with the first purpose, it can be concluded that the EU harmonization endeavors, at least as revealed by provisions of Directive 2007/36 and Directive $2017 / 828$, are genuinely motivated and worded. They demand more information provided to shareholders in order to help them to achieve an educated and active approach with the potential to influence corporate governance (Directive 2007/36) 
and dramatically increase the transparency and committed long-term engagement of shareholders especially vis-à-vis the management, including its remuneration (Directive 2017/828). Certainly, a deeper analysis of mentioned provisions and their impact on the corporate governance should be done.

Nevertheless, already at this point and based on the rather cursory overview, it can be sufficiently strongly proposed that the message of the EU is to move for harmonized, more active, better informed and long-term commited shareholders of listed companies and supporting their exercise of their rights, and so consequently re-shaping corporate governance.

Secondly, along with the second purpose, it can be concluded that tranposition processes and strategies regarding Directive 2007/36 and Directive 2017/828 are extremely diversified and different. In addition, the above presented projection of their overview, along with the case law study, points out a clear resistance. Namely, the identified well meant and worded harmonization provisions have been encountering a noticeable resistance from certain EU member states.

In sum, the performed comparative study implies a message about genuine and real EU harmonization endeavors designed to shape the exercise of shareholder's rights and specifically encouraging a long-term shareholder engagement as the vehicle to increase corporate social responsibility as well as a message about the lack (CSR).

However, it implies as well, especially from selected transposition strategies, that certain EU member states do not share such a vision of the EU and even resist and decline to do their strict minimal duty - to transpose both Directives in a duly and timely manner in their national regimes.

This leads to a crucial question urgently calling for further studies. Why do EU member states, such as France, Spain or Belgium, decline to change their national laws to make them compliant with the EU drive to support long term shareholder engagement and the exercise of rights, and ultimately to follow the EU vision about the corporate governance framework within the Strategy Europe 2020? It is highly recommended to understand the reasons, to take a bottom-up approach, to enhance awareness and to develop an open-minded dialogue.

The result of that should be a better understanding of mutual priorities and the capacity to reach a compromise in the form of a framework supporting shareholder engagement for corporate governance which will match the expectations and desires of the EU, Strategy Europe 2020, EU member states and all stakeholders of listed companies. This should increase the effectiveness, efficiency and sustainability of the current framework shaped by Directive 2007/36 and Directive 2017/828. 


\section{References:}

Areeda, Ph.E. 1996. The Socratic method. Harvard Law Review, 109(5).

Balcerzak, A.P. 2015. Europe 2020 Strategy and Structural Diversity Between Old and New Member States. Application of Zero Unitarization Method for Dynamic Analysis in the Years 2004-2013. Economics \& Sociology, 8(2), 190-210.

Balcerzak, A.P. 2016a. Technological Potential of European Economy. Proposition of Measurement with Application of Multiple Criteria Decision Analysis. Montenegrin Journal of Economics, 12(3), 7-17.

Balcerzak, A.P. 2016b. Fiscal Burden in the European Union Member States. Economic Annals - XXI, 161(9-10), 4-6.

Bansal, P. \& Song, H.C. 2017. Similar But Not the Same: Differentiating Corporate Sustainability from Corporate Responsibility. Academy of Management Annals, 11(1), 105-149. DOI: 10.5465/annals.2015.0095

Bočková, N. \& Meluzín, T. 2016. Electronics Industry: R\&D Investments as Possible Factorsof Firms Competitiveness. Procedia - Social and Behavioral Sciences, 220, 51-61.

Chirita, A.D. 2014. A legal-historical review of the EU competition rules. International and comparative law quarterly, 63 (2), 281-316.

Chronopoulos, A. 2014. Legal and economic arguments for the protection of advertising value through trade mark law. Queen Mary Journal of Intellectual Property, 4(4), 256-276.

Çolak, M.S. \& Ege, A. 2013. An Assessment of EU 2020 Strategy: Too Far to Reach? Social Indicators Research, 110(2), 659-680.

Damro, C. 2012. Market power Europe. Journal of European Public Policy, 19(5), 682-699.

Egedy, T. 2012. The effects of global economic crisis in Hungary. Hungarian Geographical Bulletin, 61(2), 155-173.

Erixon, F. 2010. The Europe 2020 strategy: time for Europe to think again. European View, 9, 29.

European Commission (2010). COM (2010) 2020 Communication from the Commission Europe 2020 - A strategy for smart, sustainable and inclusive growth. Retrieved http://ec.europa.eu/eu2020/pdf/COMPLET\%20EN\%20BARROSO\%20\%20\%2000 7\%20-\%20Europe\%202020\%20-\%20EN\%20version.pdf (18.10.2019).

Hahn, T. et al. 2018. A Paradox Perspective on Corporate Sustainability: Descriptive, Instrumental, and Normative Aspects. Journal of Business Ethics, 148, 235-248. DOI: https://doi.org/10.1007/s10551-017-3587-2.

Jędrzejowska-Schiffauer. I., Schiffauer, P., Thalassinos, E. 2019. EU Regulatory Measures Following the Crises: What Impact on Corporate Governance of Financial Institutions? European Research Studies Journal, 22(3), 432-456.

Kuckartz, U. 2014. Qualitative Text Analysis - A Guide to Methods, Practice and Using Software. Sage Publications Ltd. ISBN 978-1-446-26775-2.

Lajtkepová, E. 2016. Differences and Similarities in the Indebtedness of EU Member States after Last Financial Crisis. Oeconomia Copernicana, 7(4), 551-563.

MacGregor Pelikánová, R. 2012. And the best top level domain for European enterprises is ... International and Comparative. Law Review, 12(2), 41-57.

MacGregor Pelikánová, R. 2017. European Myriad of Approaches to Parasitic Commercial Practices. Oeconomia Copernicana, 8(2), 167-180. 
MacGregor Pelikánová, R. 2019a. The Fair Analysis of the Case law of the Court of Justice of EU on the Unfair Commerical Practices. Acta Academica Karviniensia, 19(1), 47-58.

MacGregor Pelikánová, R. 2019b. R\&D expenditure and innovation in the EU and selected member states. JEMI - Journal of Entrepreneurship, Management and Innovation, 15(1), 13-33.

MacGregor Pelikánová, R. 2019c. Corporate Social Responsibility Information in Annual Reports in the EU - Czech Case Study. Sustainability, 11, 237.

MacGregor Pelikánová, R. 2019d. Harmonization of the protection against misleading commercial practices: ongoing divergences in Central European countries. Oeconomia Copernicana, 10(2), 239-252.

MacGregor Pelikánová, R., Císařová, J., Beneš, M. 2017. The misleading perception of the purpose of the protection against misleading advertising by the EU law and its impact in the Czech Republic. The Lawyer Quarterly, 7(3), 145-161.

Margoni, T. 2016. The Protection of Sports Event in the EU: Property, Intellectual Property, Unfair Competition and Special Forms of Protection. International Review of Intellectual Property and Competition Law, 47(4), 386-417.

Melecký, L. 2018. The main achievements of the EU structural funds 2007-2013 in the EU member states: efficiency analysis of transport sector. Equilibrium. Quarterly Journal of Economics and Economic Policy, 13(2), 285-306.

Osuji, O.K. 2011. Business-to-consumer harassment, unfair commercial practices directive and the UK - a distorted picture of uniform harmonisation? Journal of Consumer Policy, 34(4), 437-453.

Pakšiová, R. 2016. CSR reporting in Slovakia. In: Proceedings of the 3rd international conference on european integration 2016. Ostrava : VŠB - Technical University of Ostrava, 698-707.

Pasimeni, F. \& Pasimeni, P. 2016. An Institutional Analysis of the Europe 2020 Strategy. Social Indicator Research, 127(3), 1021-1038. doi: 10.1007/s11205-015-1013-7.

Piekarczyk, A. 2016. Contemporary organization and a perspective on integration and development. Oeconomia Copernicana, 7(3), 467-483. doi: 10.12775/OeC.2016.027.

Polcyn, J. 2018. Human development level as a modifier of education efficiency. Management-Poland, 22(2), 171-186.

Pohulak-Żoledowska, E. 2016. Innovation in Contemporary Economies. Oeconomia Copernicana, 7(3), 451-466.

Silverman, D. 2013. Doing qualitative research - a practical handbook. London: SAGE.

Sroka, W. \& Szanto, R. 2018. Corporate Social Responsibility and Business Ethics in Controversial Sectors: Analysis of Research Results. Journal of Entrepreneurship, Management and Innovation (JEMI), 14(3), 111-126. DOI: 10.7341/20181435

Staníčková, M. 2017. Can the implementation of the Europe 2020 Strategy goals be efficient? The challenge for achieving social equality in the European Union. Equilibrium. Quarterly Journal of Economics and Economic Policy, 12(3), 383-398.

Stec, M. \& Grzeby, M. 2017. The implementation of the Strategy Europe 2020 objectives in European Union countries: the concept analysis and statistical evaluation. Quality \& Quantity, 52(1), 119-133.

Teasuro, C. \& Russo, C. 2008. Unfair commercial practices and misleading and comparative advertising: An analysis of the harmonization of EU legislation in view of the Italian implementation of the rules. Competition Policy International, 4(1), 193-222. 
Thalassinos, E., Thalassinos, Y. 2018. Financial Crises and e-Commerce: How Are They Related (October 29, 2018). Available at SSRN: https://ssrn.com/abstract=3330169 or http://dx.doi.org/10.2139/ssrn.3330169

Turečková, K. \& Nevima, J. 2017. European funds - risk management by public colleges. Scientific Papers of the University of Pardubice, Series D, 24(41), 206-216.

Tvrdoň, M. 2016. Decomposition of Unemployment: The Case of the Visegrad Group Countries. E\&M Ekonomie a Management, 19(1), 4-16.

Tvrdoň, M., Tuleja, P., Verner, T. 2012. Economic Performance and Labour Market in the Context of the Economic Crisis: Experience from the Visegrad Four Countries. E\&M Ekonomie a Management, 15(3), 16-31.

Vivant, M. 2016. Building a common culture IP? International revue of intellectual property and competition law, 47(3).

Żelazny, R., \& Pietrucha, J. 2017. Measuring innovation and institution: the creative economy index. Equilibrium. Quarterly Journal of Economics and Economic Policy, 12(1), 43-62. 